Rosa María Alemán Martínez*

UDC 304(82) Duarte E.

Autonomous University of the State of Mexico

929 Duarte E.

(Universidad Autónoma del Estado de México).

Toluca, Estado de México.

\title{
LA POLÍTICA SOCIAL DE EVA DUARTE: LA VÍA DEL EMPODERAMIENTO
}

El presente ensayo, forma parte de una investigación más amplia sobre el empoderamiento femenino y los mecanismos que promueven su liderazgo. En este documento recuperamos la historia de una mujer que en su trayectoria de vida enfrentó problemáticas y forjó un nuevo rumbo para sí misma y para el pueblo de Argentina en lo que a política social se refiere. En este escrito, es nuestra intención, mostrar los aspectos más importantes de su vida personal que la rodearon y conformaron la perspectiva política y social que adoptó, para convertirse en una mujer líder.

Key words: Empowerment, Eva Duarte, Social Politics.

\section{INTRODUCCIÓN}

Eva María Ibarguren, es una mujer que hoy día se ha convertido en un símbolo mítico. Mejor conocida como Eva Perón, en el corto tiempo que figuró en las altas esferas de la política argentina, forjó una nueva imagen de sí misma, una figura que posiblemente siempre deseó ser. Eva o Evita Perón fue una mujer con antecedentes personales no adecuados para saltar a la cumbre de las altas esferas políticas, económicas y sociales; sin embargo, es una historia que tomó un rumbo nuevo al convertirse en la esposa de Domingo Perón, futuro presidente de Argentina.

El pasado velado de Eva, se expone en diversos escritos, algunos autobiográficos, otros resultados de indagaciones en torno a la vida de esta mujer. Entre unos y otros se describe, se señala o se aclaran los asuntos que marcaron la vida de una mujer, que como muchas en Argentina, han tenido que enfrentarse a problemáticas familiares, personales y dilemas propios de cómo vivir la vida.

De orígenes sencillos, es una mujer con aspiraciones de cambio, de transformación. Ante el giro que la vida le da, tiene a su alcance las posibilidades de

*rosyalemanmtz@gmail.com 
cambiar "el origen", de transformarlo, y de establecer los aspectos que habrán de definir lo que Eva Perón es de ahora en adelante. En esta ruta, enfrenta una serie de dilemas que se pensaban superados, la falta de reconocimiento, el hecho de no ser una persona grata ante los ojos de un pequeño sector de la sociedad que en términos económicos delineaban el rumbo del país, era ya un problema que debía superar.

Pese a ello, los sectores más vulnerables, económicamente más frágiles la apoyaban, su carisma le permitió legitimarse en el ámbito de la masa, las multitudes la aclamaban. Nuevamente, la convergencia entre lo que fue su vida pasada y que se pretendía resuelta, y la labor que ahora le tocaba desempeñar, es decir, desarrollar políticas sociales, con miras a la solución de problemas que un gran sector de la sociedad enfrentaba, particularmente aquellas vinculadas con la carencia de recursos. En este marco, se gesta una figura femenina que logra el reconocimiento de la gran mayoría.

\subsection{Sus orígenes}

Eva María Ibarguren, nació el 7 de mayo de 1919, de acuerdo con los registros encontrados y mencionados tanto por el periodista Tomás Eloy Martínez (autor del libro Santa Evita, 2010), uno de los biógrafos más recocidos sobre la vida de Eva Duarte, como por la Doctora en Historia Latinoamericana por la Universidad de Colombia Marysa Navarro (autora de los libros Evita, 1994; Evita: Mitos y representaciones, 2002; y de varios capítulos de libros y ensayos sobre Eva Perón); llegó al mundo en una de las provincias más pobres de Argentina. Fue hija de un hacendado que no la reconoció legalmente como tal, a pesar de que sus hermanos mayores sí fueron registrados con el apellido paterno (este hecho también tiene discrepancias entre los biógrafos que revisaron las partidas de nacimiento en la Oficialía de los Toldos, ahora General Viamonte Partido).

Juan José Sebreli, sociólogo, historiador y crítico argentino cuenta en su libro Comediantes y mártires: ensayo contra los mitos ${ }^{1}$ (2008) cómo a pesar de los prejuicios sociales, era común en las comunidades rurales tener otra familia además de la legítima. Y dentro de esa "normalidad" se encontraba Eva, estigmatizada por su condición de hija natural, por la pobreza de su familia; la ausencia del padre y la "mala fama" de la madre por su condición de concubina. Esa realidad social,

\footnotetext{
${ }^{1}$ Se trata de un ensayo en el que el autor intenta desmitificar a cuatro personalidades argentinas entre ellas, Eva Perón. El libro fue ganador del Premio Iberoamericano DebateCasa de América en el 2009.
} 
rodeada de carencias, mantuvo a Eva María ausente de algún círculo social que la reconociese.

La propia Eva hizo un esfuerzo para dejar atrás un pasado que social y políticamente podía ser un elemento en contra de su marido al averiguarse su ilegitimidad, por ello, cambió su acta de nacimiento antes de contraer matrimonio con el entonces Coronel Perón. En esta acta de matrimonio Eva indica que nació el 7 de mayo de 1922 en el poblado de Junín, que su padre era Juan Duarte (finado) y su madre Juana Ibarguren (ama de casa), tal y como lo hace constar la Dra. Navarro en su libro Evita:

[...] cuando la proximidad de su casamiento con Perón amenazó revelar un origen que los prejuicios burgueses condenaban, o sea su condición de hija natural, hizo destruir la anotación del registro civil de General Viamonte. La partida de nacimiento que Evita obtuvo para su casamiento fue hecha según sus deseos. Indicaba que su padre era Juan Duarte y su madre Juana Ibarguren. Como lugar de nacimiento, puso Junín, pues éste era un centro jurbano mucho más importante que el pueblucho en que nació, y se sacó tres años (Navarro, 1994: 16).

En el libro Mi hermana Evita ${ }^{2}$ escrito por Erminda Duarte (1972), se hace mención de los mismos datos que Eva proporcionara en su acta matrimonial, lo anterior con el fin, según su biógrafa Marysa Navarro, "de mantener vivo el mito de Evita, destacando los aspectos más 'revolucionarios' de sus actos” (1994: 21).

\subsection{Infancia}

Tomás Eloy Martínez, Marysa Navarro y Sebreli coinciden en la creencia de que el detonador del compromiso de Eva hacia la labor social fue el intenso recuerdo que dejó en ella el velorio de su padre, del cual fueron echados y debido al empeño que la Sra. Juana mostró para que sus hijos se despidieran de su padre, lograron entrar, sólo después de que la familia legítima abandonara el lugar para no toparse con ellos (hechos narrados a los autores que conformaron su biografía por los familiares del finado, así como por algunos asistentes al funeral). Este acontecimiento propició en Eva -aún niña- una repentina conciencia sobre su pobreza, su ilegitimidad y las diferencias de clases sociales que excluyen a los desfavorecidos.

\footnotetext{
${ }^{2}$ De acuerdo con la autora, este libro se gestó a raíz de los recuerdos que le generaron el momento en que acompañada de su hermana Blanca, recibe el cuerpo de Evita en Madrid, España en el año 1971.
} 
Sin embargo, la Señora Erminda Duarte, en un intento de mantener intacto el mito generado en torno a su hermana, así como una intachable reputación de su madre ante los lectores, cuenta otra historia en su libro Mi hermana Evita:

[...] nos despedimos de nuestras hermanas, hijas del primer matrimonio de papá, que quedaban más tristes que nosotros, ya que al morir papá su orfandad era completa puesto que hacía muchos años que habían perdido a su madre (1972: 20).

Ante esta aseveración que ha sido desmentida a lo largo de la historia, sólo podemos ver la necesidad de negar los orígenes de la familia Ibarguren y al mismo tiempo sanar las tan agredidas imágenes de Eva y su madre; pues si el Señor Duarte hubiera estado casado con la Señora Ibarguren, éste habría sido velado en su propia casa, con su actual esposa y no dejarlo en Chiviloy, donde se asegura residía la esposa y sus tres hijas.

Para dar cuenta de ello, tomaremos el comentario que sobre Eva formuló uno de los personajes más afamados dentro del círculo literario argentino: Victoria Ocampo, escritora, ensayista, traductora y editora argentina, quien se oponía abiertamente al peronismo, razón por la cual estuvo presa 26 días. Victoria Ocampo, según recuerda Sebreli en su libro (2008), se negaba a hablar abiertamente de Eva Perón, a quien se refería significativamente como Eva Duarte con el afán de no mencionarla con el cariño que la gente del pueblo lo hacía, y, al mismo tiempo, negándole el vínculo con el poder a través de su nombre de casada; sin embargo, en un momento histórico Ocampo dijo que "Eva era una resentida, pero que tenía justificadas razones para serlo" (2008: 74), y ese fue el sello que cubrió el trabajo social de Eva según Sebreli "el odio a la oligarquía vacuna que dejó en ella rastros de rencor de la niña al padre estanciero que la abandonó" (2008: 74).

La pobreza de su pueblo, pero especialmente el escarnio social al que se vio sometida su familia por su ilegitimidad, obligó a la familia a mudarse a otra urbe más grande, que prometía un nuevo comienzo para todos ellos. Ya instalados en el poblado de Junín, su familia comenzó a olvidarse de su pobreza y a trabajar para mejorar su posición económica; sin embargo, nuevamente la ilegitimidad nublaría los esfuerzos de la madre (Juana) por salir de la pobreza. Habiendo establecido ésta una casa comedor para hombres sin familia, Sebreli narra cómo algunos representantes de la clase media argentina utilizaron la mala fama de la madre por el concubinato con Duarte y considerarían que esa semi pensión era en realidad un burdel donde la madre prostituía a sus hijas.

Al encontrarse sola y sin el respaldo económico del padre de sus hijos, el inicio para la Señora Juana Ibarguren y sus cinco hijos pintaba diferente y más austero que en el poblado de los Toldos. De acuerdo con las investigaciones y charlas que 
Marysa Navarro sostuvo con Erminda Duarte, fue el duro trabajo de su madre lo que sacó adelante a la numerosa familia, pero al mismo tiempo, era un ejemplo de esfuerzo y compromiso.

Una máquina de coser similar a la que utilizaba la Sra. Ibarguren se encuentra hoy exhibida en el Museo Evita, ubicado en la Ciudad de Buenos Aires, Argentina; con ello el Instituto Nacional de Investigaciones Históricas "Eva Perón", dan a entender al público asistente que fue el tesón heredado por su madre, lo que impulsó a Eva a lograr grandes cosas en su vida, tanto la ilusión de desarrollarse en la actuación, como en la de superar los ataques sufridos contra ella y su esposo por los opositores del gobierno durante el primer mandato peronista; y al mismo tiempo, lograr una reivindicación hacia la imagen de la Señora Juana Ibarguren que, fue durante varios años duramente atacada por los antiperonistas.

Fue así como transcurrió la infancia de Eva, sostenida con el humilde trabajo de su madre y desprovista de aquellos lujos de los cuales gozaría durante el mandato de su esposo. Sin embargo, tanto Marysa Navarro como Erminda Duarte harán hincapié en sus respectivos libros sobre lo feliz que fue Eva en sus años de infancia junto a sus hermanos en el poblado de Junín.

Cuando Evita hizo la primera comunión tuvo que quedarse sin la foto que le sacaron pues era un gasto demasiado grande para el presupuesto de la familia. Sin embargo, era una niña alegre, inquieta, siempre dispuesta a inventar cosas para compensar lo que su madre no le podía comprar. El círculo familiar, en el que reinaba indiscutiblemente doña Juana, la cobijaba y además le daba a Chicha para seguirla en sus juegos y a Juancito para ayudarla a construir una casa en miniatura o armarle un piano con un cajón de embalaje y unos trozos de lata (1994: 23).

De acuerdo con las investigaciones de Marysa Navarro (1994), Eva fue una alumna regular, con problemas frecuentes en el área de matemáticas, pero destacaba en ella una fascinación por la recitación. Al parecer cuando el ausentismo de los alumnos se extendía para todos los grados de la escuela, Eva tenía permitido declamar ante sus compañeros: "Los días de lluvia cuando faltaban muchas niñas y se hacía difícil el trabajo regular, Evita tenía permiso para salir de su clase e ir a otras aulas para entretener a los alumnos" (1994: 28).

Desde pequeña Eva tenía algo que decir, quería compartirlo con su familia, con la gente que la conocía y también con aquellas personas que ignoraban su existencia; su necesidad de ser escuchada y sus esperanzas se trasladaron con ella a la capital federal de su país natal, Buenos Aires. 


\subsection{Buenos Aires y la Fama}

Eva María Duarte Ibarguren, a pesar de no haber sido legalmente reconocida por su padre, firmaba con el apellido que les dio éste al resto de sus hermanos y con este sello inicia el sueño que la lleva a Buenos Aires, participando en pequeñas obras de teatro, y posteriormente en la radio. Este trabajo como actriz le permite vivir en otra parte de la ciudad, un poco más alejada de la miseria a la que tanto temió.

De acuerdo con Sebreli, Eva decidió irse a Buenos Aires e intentó trabajar en el medio artístico. Así fue pues como inició la aventura de la actuación, en la que no tuvo mayor éxito, pero al mismo tiempo esos mismos papeles la irían preparando para interpretar el mejor de su carrera actoral, el de Evita Perón.

A medida que avanzaba en la vida, eso sí, el problema me rodeaba cada día más. Tal vez por eso intenté evadirme de mi misma, olvidarme de mi único tema y me entregué intensamente a mi extraña y profunda vocación artística (1951: 11).

Eva explica en su libro La razón de mi vida (1951) cómo fue que la injusticia la aleja de su pueblo y la hace anhelar ser actriz, pues es a través de la fantasía que ella podrá salir de su tan agobiante realidad, al representar otros roles que no estaban destinados para ella en la vida cotidiana.

En el lugar donde pasé mi infancia los pobres eran mucho más que los ricos, pero traté de convencerme de que debía haber otros lugares de mi país y del mundo en que las cosas ocurriesen de otra manera y fuesen más bien al revés. Me figuraba por ejemplo que las grandes ciudades eran lugares maravillosos donde no se daba otra cosa que la riqueza; y todo lo que oía yo decir a la gente confirmaba esa creencia mía. Hablaban de la gran ciudad como de un paraíso maravilloso donde todo era lindo y era extraordinario y hasta me parecía entender, de lo que decían, que incluso las personas eran allá 'más personas' que las de mi pueblo (1951: 24).

Nuevamente Erminda Duarte intentó acallar con su libro las injurias lanzadas sobre su hermana y su deseo mal visto de ser actriz, pues los comentarios insinuaban que se había ido sin permiso de la madre a Buenos Aires para seguir su sueño:

Recitaste una poesía de Amado Nervo ¿A dónde van los muertos? Lo recitaste con tal estremecimiento de tu sensibilidad, desentrañando tan patéticamente su contenido, que el Director de Radio Nacional, que entonces era Pablo Osvaldo Valle, que te había oído, pidió que te condujeran a su presencia. Entraste a su despacho acompañada por mamá. Instantes después firmabas un pequeño contrato (1972: 71).

A pesar de su entusiasmo y pasión por la actuación y declamación, su falta de preparación académica y social nuevamente la marginó en ese nuevo contexto en el 
que ahora se desenvolvía: el artístico. Pues tanto para los empresarios teatrales, como para sus compañeros de trabajo, no tenía talento, ni buena dicción, ni tampoco sabía bailar o cantar; su mayor logro fueron sus apariciones en las fotografías de Wilenski y Annemarie Heinrich, pero su belleza no se ajustaba a los cánones establecidos en la época, de acuerdo con lo que relata Sebreli sobre la etapa artística de Eva.

El autor refiere que en los años artísticos de Eva sólo había dos roles que la mujer podía interpretar, uno era denominado el blanco en el que las actrices sugerían la candidez, la ingenuidad y el carisma de la mujer casi virginal; por otro lado estaba el papel negro en el que se interpretaba a las mujeres malas, fuertes, dominadoras, dando la idea de la femme fatal. Para infortunio de Eva, su imagen no encajaba en el rol blanco y su falta de experiencia le impedía adentrarse en el rol negro. Sus discursos, en ambos roles, para Sebreli, eran planos y carentes de toda emotividad o veracidad (2008: 108).

Sin embargo, a pesar de la carencia de expresividad oral o de imagen y su falta de calidad interpretativa, con su mala dicción y su falta de argumentos, Eva pronunció los discursos más recordados y concurridos en la historia de Argentina; su escenario fue la propia Plaza de Mayo y su auditorio fueron miles de obreros, campesinos, amas de casa, cantantes, actores y demás personas que se acercaron a la famosa plaza para escucharla en varias ocasiones.

\subsection{Principios del Peronismo}

En el año de 1943, Argentina tenía una perspectiva política sumida entre la alternancia de los gobiernos civiles y militares. Ante la poca confianza que los militares depositaban en los políticos, surge en ellos la necesidad de congregarse y formar el Grupo de Oficiales Unidos (GOU) para buscar un sentimiento de nacionalismo en los ciudadanos y alejarlos al mismo tiempo del catolicismo y el pensamiento anticomunista.

Al llegar el General Edelmiro Farrell (uno de los miembros más activos al interior del GOU) a la Vicepresidencia; nombró al entonces Coronel Juan Domingo Perón Director del Departamento Nacional del Trabajo. (Datos registrados en el libro Los Nacionalistas de Marysa Navarro 1965:94).

El Coronel Perón estaba estrechamente vinculado a la milicia así como al GOU y fue asumiendo diversos puestos a nivel político: Secretario del Trabajo y Previsión, Ministro de Guerra y, en el año 1945 Vicepresidente de la Nación.

Gracias a su cargo como Secretario del Trabajo y Previsión, los lazos entre el Coronel Perón y los trabajadores, así como las organizaciones formadas por ellos, se fueron estrechando debido a que durante su gestión se establecieron varios avances 
para el desarrollo y bienestar de los trabajadores tales como: el salario mínimo, el aguinaldo, la creación de tribunales laborales, los convenios colectivos, la extensión de vacaciones pagadas, el estatuto del peón, las organizaciones sindicales, entre otras (1965: 102).

Juan Domingo Perón tenía ya varios seguidores en la política y fuera de ella gracias a las mejoras laborales que había propiciado, por tal motivo el Presidente Farrell y los miembros más altos en la milicia le retiran su apoyo y la Secretaría a su cargo; sin embargo, antes de partir Perón logra pronunciar un discurso ante los sindicatos que se habían formado y en éste les aclara que ha dejado firmado un decreto de aumento salarial. La oficina presidencial toma el discurso como una desobediencia directa y lo apresan en septiembre de 1945. La reacción de sus seguidores derivó en la organización de una marcha que se llevó a cabo el 17 de octubre del mismo año a favor del Coronel exigiendo su inmediata libertad, fue tal la movilización sindical y la presión social, que los políticos contrarios a Juan Domingo Perón cedieron y fue liberado ese mismo día, convirtiéndose así en el próximo candidato presidencial de los trabajadores.

Debido a la labor que realizó en favor de los obreros argentinos cuando era Secretario del Trabajo, tuvo el apoyo de la Confederación General del Trabajo (CGT) para constituir así el Partido Laborista (PL) por el cual llega a la Presidencia de Argentina en el año 1946.

Varios fueron los puntos que determinaron la labor del Presidente Perón; sin embargo, para este trabajo tomaremos en consideración dos de ellos en los cuales tuvo una marcada participación y reconocimiento Eva Perón: el Sufragio Femenino y la Política Social en su primer periodo presidencial.

\subsection{La Política Social y la "Compañera Evita”}

De acuerdo con los datos arrojados por el Instituto Nacional de Investigaciones Históricas Eva Perón, fue a raíz del terremoto que dejó destruida la Ciudad de San Juan, en el año 1944, dónde hubo alrededor de 7,000 decesos y la casi desaparición de la ciudad, lo que propició que el gobierno encabezado por el General Pedro Pablo Ramírez entrara en auxilio a los damnificados. Fue entonces que bajo el mando del Coronel Juan Domingo Perón como Secretario de Trabajo y Asistencia Social, se realizaron campañas de recaudación de fondos.

En el marco de las campañas de apoyo a las víctimas del sismo, el 22 de enero de 1944 se llevó a cabo por parte de la comunidad artística de la Argentina, un festival en el estadio Luna Park. Al festival se unieron personalidades artísticas de la época como el maestro de orquesta Francisco Canaro, Libertad Lamarque, Hugo del 
Carril y la debutante teatral Eva Duarte entre otros. El propio Juan Domingo Perón relata en su libro Del poder al exilio: cómo y quiénes me derrocaron ${ }^{3}$ (2006) el recuerdo que mantenía de aquel día que conoció a la actriz Eva Duarte:

Eva entró en mi vida como el destino. Fue un trágico terremoto que sacudió la provincia de San Juan, en la cordillera, y destruyó casi enteramente la ciudad, el que me hizo encontrar a mi mujer. En aquella época yo era ministro de Trabajo y Asistencia Social. La tragedia de San Juan era una calamidad nacional. Para socorrer a la población movilicé al país entero; llamé a hombres y mujeres a fin de que todos tendiesen la mano a aquella pobre gente de aquella provincia remota. Entre los tantos que en aquellos días pasaron por mi despacho, había una joven dama de aspecto frágil, pero de voz resuelta, con los cabellos rubios y largos cayéndoles a la espalda, los ojos encendidos como por la fiebre. Dijo llamarse Eva Duarte, ser una actriz de teatro y de la radio y querer concurrir, a toda costa, a la obra de socorro para la infeliz población de San Juan" (2006: 75).

El periodista Tomás Eloy Martínez (2010) escribe los testimonios de las personas que conocieron a Eva en esos años y la presentan como una mujer poco agraciada, torpe en su andar y hablar; sin embargo, reconocieron en ella a una mujer empática; lo que le permitió entenderse de inmediato con la clase humilde; beneficiando a su esposo Juan Domingo Perón, pues éste aludía en sus discursos que había salido del pueblo y pretendía trabajar para él.

El Coronel y la actriz inician una relación que se sellaría en matrimonio a finales del año 1945. Juan Domingo Perón asumió la presidencia de su país por elección popular en 1946. Es en este preciso año donde inicia nuestro recorrido a través de los ojos que vieron a Eva María Duarte Ibarguren transformarse en Evita Perón.

Esta transformación se produce en Eva Duarte, debido, fundamentalmente, a su condición de consorte y, posteriormente, cuando asume el liderazgo en la política social que se desarrolló durante la administración de Perón. Estos trabajos que realizó en pro de los más desfavorecidos, la legitimaron ante el pueblo argentino y le otorgaron el poder carismático que le permitió convocarlos y solicitarles apoyo para sostener el gobierno de su esposo Juan Domingo Perón.

Su evolución personal se ve, de acuerdo con las personas entrevistadas por el periodista Tomás Eloy Martínez, desde su forma de andar hasta sus peinados y, por

\footnotetext{
${ }^{3}$ Durante su exilio, el ex presidente Perón comenzó a escribir una serie de artículos que se publicarían en Italia y los cuales posteriormente integrarían su libro: Del poder al exilio. Cómo y quiénes me derrocaron.
} 
supuesto, las prendas que hasta el final de su vida usó. Pero los elementos esenciales que demuestran la fuerza de su personalidad y el empoderamiento socio - político que tuvo, están reflejados en la toma de decisiones y el trabajo cotidiano que realizaba con la gente. La ausencia de hijos según el periodista la llevó a ejercer la maternidad simbólica, al convertirse en una suerte de madre de los pobres en Argentina.

Para Sebreli (2008), el proceso de transformación y empoderamiento que inició Eva ocurrió desde el instante en que aceptó ser la imagen de la esposa tradicional pero actuar como revolucionaria. Las convenciones sociales de la época, así como su lujoso vestuario pretendían hacer de Eva un objeto de ornato en el periodo peronista. Su extremada subordinación hacia el varón -en este caso hacia su esposo- era el único medio por el cual lograría justificar su participación en la política social. Perón delegó en ella el manejo de la política social de su periodo presidencial.

La parte contradictoria, para muchos de sus biógrafos, así como para los antiperonistas y peronistas mismos, fue el rol que Eva decidió aceptar y representar como la gran e incondicional compañera; pero al mismo tiempo era activa dentro del otro rol, el de luchadora por una causa que ella creía justa: el trabajo por los pobres.

-¿Cómo va usted -me decían- a dirigir un movimiento feminista si usted está fanáticamente enamorada de la causa de un hombre?

No, no lo es. Yo lo "sentía". Ahora lo sé.

La verdad, lo lógico, lo razonable es que el feminismo no se aparte de la naturaleza misma de la mujer.

Y lo natural en la mujer es darse, entregarse por amor, que en esa entrega está su gloria, su salvación, su eternidad.

¿El mejor movimiento feminista del mundo será tal vez entonces el que se entrega por amor a la causa y a la doctrina de un hombre que ha demostrado serlo en toda la extensión de la palabra?

De la misma manera que una mujer alcanza su eternidad y su gloria y se salva de la soledad y de la muerte dándose por amor a un hombre, yo pienso que tal vez ningún movimiento feminista alcanzará en el mundo gloria y eternidad si no se entrega a la causa de un hombre.

¡Lo importante es que la causa y el hombre sean dignos de recibir esa entrega total! (1951: 48,49)

Una vez en el poder Juan Domingo Perón, Eva Duarte se negó a llevar la vida de Primera Dama que hasta entonces se conocía. Solicitó un espacio físico al cual la gente pudiera acudir a ella y a la que se le pudiera atender de manera inmediata y personalizada. Así pues, la Primera Dama se dio a la tarea de escuchar, atender y 
solucionar los problemas que aquejaban a los miembros de la clase trabajadora que se acercaban a ella.

No se limitó a la atención de los problemas económicos que acarrean la cotidianidad de las personas, también se vio envuelta en las charlas que el gobierno sostenía con los sindicatos de los trabajadores ferroviarios y mineros, trabajo que le fue encomendado por el Presidente Juan Domingo Perón en persona.

A pesar de haber aceptado el papel de esposa del presidente que asistiría con él a los eventos públicos, Eva misma reconoció que había en ella otra faceta que a la postre le interesaría más que el rol de Primera Dama:

Pero, además, yo no era solamente la esposa del Presidente de la República, era también la mujer del conductor de los argentinos.

A la doble personalidad de Perón debía corresponder una doble personalidad de mí: una, la de Eva Perón, mujer del Presidente, cuyo trabajo es sencillo y agradable, trabajo de los días de fiesta, de recibir honores, de funciones de gala; y otra, la de Evita, mujer del líder de un pueblo [...]

Unos pocos días al año, represento el papel de Eva Perón [...] La inmensa mayoría de los días soy en cambio Evita, puente tendido entre las esperanzas del pueblo y las manos realizadoras de Perón, primera peronista argentina, y éste sí que me resulta papel difícil, y en el que nunca estoy totalmente contenta de mí. (1951: 67)

De esta manera, se da inicio el acercamiento de Eva Duarte a la gente; a los problemas sociales, económicos y políticos de la nación y su población. Según Tomás Eloy Martínez, ninguna persona se había ganado tanto el reconocimiento de la gente como Eva; su trabajo que iba desde tempranas horas de la mañana hasta ya entrada la noche; hacía que las personas que la visitaban en busca de soluciones creyeran en ella.

Eva Duarte fue reconocida no sólo por la labor que realizó con la gente de Argentina, también por la lealtad desmedida que profería a su esposo Juan Domingo Perón. Por ello, el vínculo que existía entre ambos le lleva a ser reconocida como Eva Perón. La agenda que como Primera Dama llevó, estaba cargada de temas relacionados con la pobreza y la desigualdad social. Aunque no asumió posturas feministas, algunos de sus biógrafos coinciden en que puso ante el Congreso de su Nación la propuesta para legalizar el voto de la mujer, así como la ayuda económica y laboral a madres solteras.

Cabe mencionar que las mujeres peronistas, y aquellas que pertenecían a la fundación Eva Perón, asistieron a marchas convocadas por el despacho de Eva Perón; sin embargo, Eva nunca acudió a ninguna de las marchas registradas por el periódico La Nación de 1948 debido a su estado de salud. Por tal motivo, Juan José Sebreli se 
lanza junto con otros personajes de Argentina como Jorge Luis Borges, a criticar férreamente la interferencia de Eva en la política, dado que ella nunca se había interesado en los derechos cívicos de la mujer y mucho menos en los movimientos feministas; a pesar de ello, se le otorga como regalo la aprobación de la Ley del voto femenino. Para Sebreli la apropiación de esta ley, por parte de Eva, incurre en una falsificación histórica y deja de lado y en el total olvido la lucha de las sufragistas que lograron integrar en el Programa Electoral de Perón; la aceptación del voto sin la intervención de Eva.

Sin embargo, a través de la Presidencia de la Nación, la Secretaría de Cultura y el Instituto Nacional de Investigaciones Históricas Eva Perón de la República de Argentina, se imprimen en 2007 los cuadernillos sobre "Sufragio Femenino: Algo más que un trámite legal"; en el cual otorgan abierta y plenamente el logro del voto femenino en la Argentina a la propuesta y trabajo de Eva Perón.

El escrito enuncia los discursos que Eva Perón pronunciaría a lo largo de los años 1946 y 1947 a favor del sufragio femenino de las mujeres argentinas, en su país y durante su gira en Europa.

Arduos fueron los trabajos de las sufragistas que derivaron en las dos sesiones de debate que se llevaron a cabo en la Cámara Baja del Congreso; las mujeres arremolinadas en las galerías esperaban ansiosas las resoluciones mientras escuchaban a diversos oradores sus discernimientos sobre las ventajas y desventajas que traería a la nación el voto femenino.

Mientras los diputados exhibían sus dotes oratorias y revitalizaban en sus exaltaciones 'a la mujer', afuera, en la explanada que se extiende frente al Congreso, varios miles de mujeres esperaban con impaciencia el resultado de sus liberaciones. Al grito de '¡Uno, dos, tres, que se apruebe de una vez!' y '¿Queremos el voto!', sacudían enormes carteles, banderas y grandes retratos de Perón y Evita. (La Nación 11 de septiembre de 1947)

Tras la dura jornada de debates y consensos, las mujeres de la galería eran acompañadas por una Eva Perón enferma en la espera de la aprobación de ley. Finalmente la iniciativa fue aprobada y en agradecimiento al apoyo recibido por parte de Eva las sufragistas le otorgan el logro de la Ley 13010 en la cual a partir del 23 de septiembre de 1947 se declara que "Las mujeres argentinas tendrán los mismos derechos políticos y estarán sujetas a las mismas obligaciones que acuerdan o imponen las leyes a los varones argentinos" (2007: 35).

Ante este logro obtenido por parte de las mujeres, Eva Perón hizo un comentario final sobre el evento dirigido a sus compañeras y a las mujeres de toda Argentina a través de la radio nacional: "Nuestra voz ha sido escuchada. Gracias a la 
Revolución y a nuestro Líder se han reconocido al fin los derechos políticos que durante tanto tiempo nos fueron negados. Ahora podemos votar. Mujeres compatriotas, amigas mías, ¡Sepamos también votar!" (La Prensa 12 de septiembre de 1947).

En el Museo Eva Perón se ubica una sección destinada al logro del voto femenino, el cual es narrado a través de varias imágenes alusivas al proceso; sin embargo, destaca una en especial fechada el 23 de septiembre de 1947, en la que se encuentra una gran concentración reunida en la Plaza de Mayo aclamando la ley y otorgándole el triunfo a Evita.

Fuente: Museo Eva Perón (Buenos Aires, Argentina)

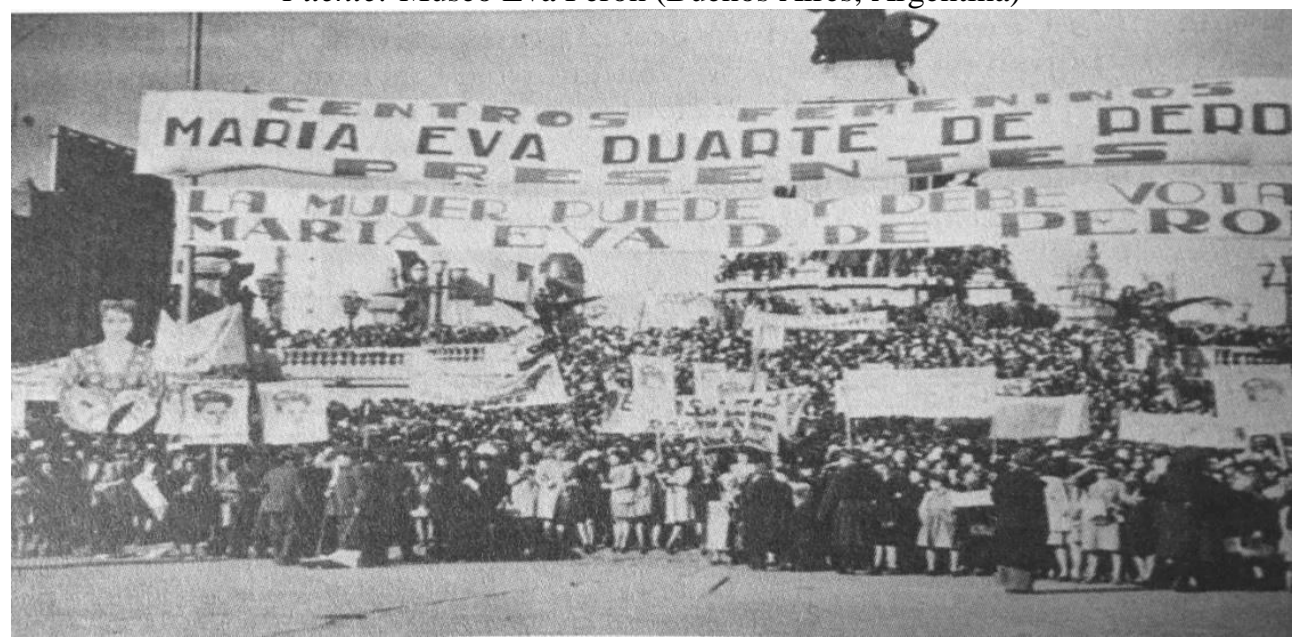

1.6 De la beneficencia a la justicia social

De acuerdo con el Acta de Instalación de la Sociedad de Beneficencia, fue el 2 de enero de 1823 que se creó la Sociedad de Beneficencia, la cual tendría como responsabilidad la "dirección e inspección de las escuelas para niñas, la casa de partos públicos y ocultos, hospitales de mujeres y el colegio de huérfanas y todo establecimiento público dirigido al bien de los individuos de este sexo" (1823).

La conformación de las instancias de ayuda social tenían como objeto preservar el bienestar de la población femenina y mantener al mismo tiempo la "perfección de la moral, el cultivo del espíritu en el bello sexo y la dedicación del mismo a lo que se llama industria" (1823). A finales del siglo XIX se convirtió en la Sociedad de Institutos de Minoridad y Centros de Salud de ambos sexos (1908). El funcionamiento de ambas instituciones dependía de las donaciones públicas, aportes del Estado y colectas a través de eventos sociales. 
En el marco de la Política Social llevada a cabo en el primer gobierno peronista surgió la Fundación Eva Perón, la cual representó un giro en la presentación y aplicación de esta política. A partir de su integración se pensó en la modernización, reestructuración y ampliación de toda la infraestructura y el personal a cargo de la labor social (2001: 4).

La época de la política social vista desde el trabajador había iniciado con el Coronel Perón al frente de la Secretaría del Trabajo y Previsión, el hecho de que Perón llegara a la Presidencia en 1946 sólo afianzó las medidas sociales, pero en esta ocasión no estarían lideradas por él. A partir de entonces y por designio Presidencial, sería la Primera Dama Eva Duarte la encargada de realizar las acciones correspondientes para mejorar y concretar los trabajos sociales.

El 14 de junio de 1946, doscientos empleados de la Sociedad de Beneficencia firmaron un documento en el cual exponían la precariedad de su situación laboral, así como la de su compensación salarial (1965: 136). El Senado tenía ya la encomienda de propiciar un cambio; el decreto No. 941446/46 estableció intervenir en la Sociedad de Beneficencia de normas técnicas y propicias de asistencia y previsión social (2001: 5).

De acuerdo con el Instituto Nacional de Investigaciones Históricas Eva Perón, la Primera Dama, comenzó a desarrollar sus actividades, solicitando la intervención del Presidente Perón ante varias compañías con el fin de mejorar la vida de los obreros, recorría los barrios humildes, distribuía ropa, alimentos y daba solución a los casos que a través de cartas llegaban a la Residencia Presidencial.

Eva bien pudo haber vislumbrado que la labor que iniciaba era de gran magnitud y por ello tuvo ayuda de la casa presidencial directamente. Uno de los garajes de la casa se habilitó para recibir los donativos de ropa y alimentos que se recibían; el cocinero, los mozos y las mucamas ayudaban a ordenarlo.

\subsection{Justicia Social}

El concepto de justicia social surgió durante el siglo XIX, muchos años después de la materialización de la Revolución Francesa en la cual se lograron determinar varios conceptos para el desarrollo humano. La finalidad del concepto y su aplicación es el de lograr un reparto equitativo de los bienes sociales, dentro de una sociedad con justicia social en la cual las clases más desfavorecidas cuenten con oportunidades de desarrollo.

El origen de la justicia social se encuentra dentro de la justicia distributiva que se encuentra redactada y defendida en la "Declaración de Derechos del Hombre y del Ciudadano" firmada en 1789. Esta justicia deja firmemente establecido que 
todas las personas deben disfrutar y tener acceso a los bienes imprescindibles de la educación y la alimentación como desarrollo del hombre.

Fue el 20 de febrero de 2007 que la Organización de Naciones Unidas (ONU) establece el "Día Internacional de la Justicia Social", en el que se aboga por celebrar mediante actividades el fomento a la dignidad humana, el desarrollo, el pleno empleo y la igualdad entre géneros y el bienestar social.

La justicia social es el compromiso que el Estado adquiere ante su pueblo para compensar las desigualdades que surgen en las economías y en otros ámbitos sociales. Es la autoridad la que debe propiciar las condiciones óptimas para que el pueblo logre su desarrollo económico, esto quiere decir, que el porcentaje de gente rica o de riqueza debe de estar sólo en manos de unos cuantos.

El origen y lo vivido en su propia realidad generó en Eva Duarte un sentimiento de deuda en la sociedad argentina para con los más desfavorecidos. El trabajo que emprendió de cara a la sociedad argentina, le permitió ver el incremento en número, variación y urgencia de las necesidades del pueblo, Eva decidió emprender un viaje a Europa cuyo objetivo sería el de reproducir las obras públicas y los medios de los que se valían para su atención y la propagación de ayuda a la población más desfavorecida. Su reacción y sentimiento ante aquellas obras sociales le hicieron actuar diferente, y lo recuerda en su libro La razón de mi vida (1951) "La obras sociales de Europa son, en su mayoría, frías y pobres. Muchas obras han sido construidas con criterio de ricos y el rico, cuando piensa para el pobre, piensa en pobre. Otras han sido hechas con criterio de estado; y el Estado sólo construye burocráticamente, vale decir con frialdad en la que el gran ausente es el amor" (180, 181).

A su regreso decidió emprender sus propias acciones, contando con la ayuda de los participantes de la Cruzada de Ayuda Social María Eva Duarte de Perón, la cual quedó constituida el 19 de junio de 1948 como Fundación de Ayuda Social María Eva Duarte de Perón, a través del decreto No. 220.564.

En 1950 por medio del decreto No. 20268 cambió su nombre por el de Fundación Eva Perón, estableciendo:

La administración corresponde única y exclusivamente a su fundadora, Doña María Eva Duarte de Perón, quien ejercerá con carácter vitalicio y gozará de las más amplias atribuciones que las leyes y el Estado conceden a las personas jurídicas. Sin perjuicio de lo expuesto, la fundadora podrá, cuando lo estime conveniente y a su solo arbitrio, designar consejos, delegaciones y mandatarios generales y especiales. Dichos consejos, delegaciones o mandatarios, durarán el tiempo que la fundadora determine y ejercerán, por delegación de ésta, las facultades que se 
determinen en sus respectivas designaciones (Memoria y Balance de la Fundación Eva Perón al 31 de julio de 1952).

La Fundación aseguró fondos a través de donativos en efectivo o en especie por parte de personas físicas y morales; así como por las leyes dispuestas por el poder ejecutivo entre las cuales el Instituto menciona: la ley 13941, impuesto adicional a la venta de boletos en el Hipódromo Argentino y la ley 13.992.

\subsection{Asistencia Social}

La Organización Mundial del Trabajo define a la asistencia social como una actividad que se encarga de diferentes rubros sociales, entre los que destacan el promover un cambio social hacia un estado de desarrollo para los individuos, la resolución de los conflictos humanos y el fortalecimiento de los pueblos para alcanzar el bien común.

De acuerdo con la Organización Internacional del Trabajo, las relaciones entre individuos y especialmente entre individuos con diferente poder adquisitivo, genera conflictos o bien la demora en la justicia que salvaguarde los derechos de los más desfavorecidos. Por ello, la asistencia social procura que todos los miembros de la sociedad tengan las mismas oportunidades y disfruten de los mismos derechos sin distinción alguna.

Para alcanzar sus objetivos en materia de asistencia social, el Estado propicia la creación de instituciones y de manera más actual, organizaciones no gubernamentales o fundaciones que se ocupen de analizar y solventar las necesidades sociales a través del Estado mismo o en caso de no poseer liquidez, se hará uso de las donaciones sociales.

La asistencia social, básicamente procurará que todas las personas desarrollen lo más plena y satisfactoriamente posible sus potencialidades, que enriquezcan sus vidas y que se prevengan de cualquier tipo de disfunción que los aleje de la felicidad y el bien común. ${ }^{4}$

Tomando como base la premisa de propiciar la felicidad en todos los integrantes de una sociedad, las primeras obras que desarrolló la Fundación Eva Perón fueron los Tres Hogares de Tránsito, cuyo objetivo era brindar vivienda momentánea al que carecía de ella debido a la situación económica que enfrentaba

\footnotetext{
4 Ver http://www.ilo.org/wcmsp5/groups/public/---dgreports/---cabinet/documents/generic document/wcms_371206.pdf. Consultado el 4 de abril de 2017.
} 
el país. La permanencia en estas residencias duraba hasta que la Fundación les encontraba a las personas que ahí se alojaban un trabajo fijo y vivienda.

Otro proyecto estuvo dirigido nuevamente para el apoyo a las mujeres, sólo que en esta ocasión era para aquellas que le hacían recordar a Eva sus precarios inicios en la capital del país. Por ello, construyó el Hogar de la Empleada (2001: 16), en el cual tenían cabida aquellas mujeres que contaran con trabajo remunerado de quinientos pesos o menos, de esta manera tenían acceso al edificio de 500 habitaciones y al restaurante con precios accesibles que abría sus puertas a todo el público.

Para la Fundación Eva Perón, todos aquellos sectores sociales que habían sido descuidados por los gobiernos anteriores al de Perón fueron los primeros en su agenda. Cuenta de ello es el programa a la Ancianidad Desvalida (2001: 18), aludiendo que: "no había país más grande si no empezaba por proteger y respetar a los ancianos; que no podía haber país más grande si no se ayudaba al que todo lo había dado a la Patria y, en el ocaso de su vida, se veía en la necesidad de recurrir a la ayuda de sus hermanos" (Discurso pronunciado por Eva Perón el 28 de agosto de 1948 sobre la Declaración de los Derechos de la Ancianidad, en solemne ceremonia realizada en el Ministerio de Trabajo).

El cuarto proyecto abarcó la Política Social Peronista a través de la Fundación Eva Perón se centró en otro sector vulnerable de la sociedad, los niños. Por tal motivo se crearon los Hogares Escuela (2001: 22), en los que se proveía a la infancia menos favorecida de los cuidados esenciales para su desarrollo.

Por otro lado, la Fundación Eva Perón también centró sus esfuerzos en el proyecto de Asistencia Médica, el cual iba de la mano con las obras de gobierno en materia de asistencia sanitaria y que habían sido establecidas por el Ministro Carrillo y explicadas en el "Plan Analítico de Salud Pública" . El Plan comprendía la construcción de Centros de Salud en varias provincias de Argentina, así como en diversas colonias de Buenos Aires.

La Fundación podía disponer de los Policlínicos para la atención gratuita e inmediata que requiriera cualquier persona que estuviera incluida o no en los proyectos de la asistencia social a petición de la fundadora; sin embargo, la Fundación también contaba con sus propios centros de atención, entre ellos la Clínica de Recuperación Infantil, el Instituto de Quemados, el Hospital de Clínica y Cirugía Torácica y el Tren Sanitario (2001: 28).

La misión sanitaria del tren inició con la renta de un tren que salía desde la estación central de Buenos Aires e iba recorriendo las provincias más alejadas y desprovistas de especialidades médicas. Los servicios que se prestaban en el tren eran tan diversos como el personal médico que lo ocupaba, ya que entre ellos se 
encontraban: médicos generales, odontólogos, ginecólogos, médicos clínicos, cirujanos, oftalmólogos, otorrinolaringólogos y enfermeras, las cuales habían egresado de la Escuela de Enfermeras (2001: 29) que integró la Fundación en el año 1950.

De esta manera funcionaba la Política Social en la época peronista, con planes definidos y auspiciados por el gobierno pero integrados y aterrizados con la visión de una mujer cuyo objetivo era atender de manera integral a los individuos que necesitasen el apoyo del gobierno, desarrollando en ellos(as) la salud y el bienestar físico, emocional y espiritual que conforma a cada individuo.

Todos los proyectos aportaban una mejora a la nación, los hogares de tránsito y el hogar de la empleada intentaban sacar adelante a las mujeres que se encontraban momentáneamente en problemas debido a las carencias familiares o a las circunstancias laborales; el hogar del anciano se preocuparía por la ancianidad olvidada y los hogares escuela darían solución económica y académica a los problemas de los infantes menos favorecidos.

Después de la muerte de Eva Perón en 1952, la fundación continúo su labor hasta 1955, año en que el Presidente Juan Domingo Perón se exilió en el extranjero para no ser capturado por sus opositores. Los proyectos de la política social de Perón cayeron con él sin importar el bienestar que habían llevado a la población, sin tomarse en cuenta los resultados obtenidos como la disminución de madres solteras, muertes de mujeres y niños en los partos, mejora sanitaria en la población, disminución de personas en situación de calle, niños(as) abusados y una larga lista de personas que habían sido atendidas por la Fundación y por la misma Evita en persona (Memoria de la Fundación Eva Perón).

La enorme cantidad de obras sociales que realizó Eva a través de la Fundación Eva Perón le proporcionó un papel protagónico en la vida de las personas que apoyó, y al mismo tiempo le otorgó un lugar en la historia de Argentina que hasta la fecha la recuerda con cariño.

Eva Perón, es el referente hoy de un gran número de mujeres argentinas que se identifican con ella, por su liderazgo, carisma y fortaleza para superar los obstáculos que la vida política le planteó. De orígenes sencillos, fue una mujer con una infancia difícil; sin embargo, su futuro cambió al establecer una relación y matrimonio con el General Domingo Perón. A partir de ahí, su incorporación a la vida en el ámbito político le permitió hacer uso de los recursos con los que ahora contaba. La política social que desarrolló Eva Perón, como esposa del Presidente argentino, le llevó a ganar la atención de sectores sociales con diversas necesidades. 
Desde esta perspectiva, se convirtió en una mujer cuyo empoderamiento la situó como una de las mujeres más importantes de América.

\section{Rosa María Alemán Martínez}

\section{THE SOCIAL POLITICS OF EVA DUARTE: THE ROAD TO EMPOWERMENT}

\section{Summary}

The present paper is part of the research into female empowerment and the elements that contribute to leadership. In this document we recover the history of a woman who confronted different problems and created a new future for herself and for her people in Argentina, owing to her ability to improve social politics of her nation. Our intention is to show some more important aspects of her personal life and the way those aspects influenced her political and social perspective to become a leader.

Key words: Empowerment, Eva Duarte, Social Politics.

\section{Rosa María Alemán Martínez}

\section{SOCIJALNA POLITIKA EVE DUARTE: PUT OSNAŽIVANJA}

\section{Rezime}

Rad predstavlja deo šireg istraživanja o osnaživanju žena i elementima koji jačaju vođstvo. Predstavljena je istorija (biografija) žene koja se suočava sa različitim problemima stvarajući novu budućnost kako za sebe tako i za argentinski narod, zahvaljujući njenom veštom uključivanju u socijalnu politiku nacije. Namera je da se u radu istaknu najznačajniji aspekti njenog ličnog života, kao i način na koji su ti aspekti uticali da postane vođa u političkom i socijalnom smislu.

Ključne reči: jačanje moći, Eva Duarte, socijalna politika

\section{BIBLIOGRAFÍA}

Acta de Instalación de la Sociedad de Beneficencia. Bs. As. 12 de abril de 1823.

Asistencia Social. http://www.un.org/es/events/socialjusticeday/

Consultado el 02 de abril de 2017.

Castiñeiras, Noemí (2001). Fundación Eva Perón: desde sus inicios hasta la muerte de Evita. Instituto Nacional de Investigaciones Históricas Eva Perón. M. Chilavert. Buenos Aires.

(2007). Sufragio Femenino: algo más que un trámite legal. Instituto Nacional de Investigaciones Históricas Eva Perón. M. Chilavert. Buenos Aires. 
Diario de Sesiones de la Cámara de Diputados, año 1908.

Duarte, Erminda (1972). Mi hermana Evita. Ediciones "Centro de Estudios Eva Perón". Buenos Aires.

Eloy Martínez, Tomás (2010). Santa Evita. Madrid. Santillana Ediciones Generales S. L.

Main, Mary (1956). Eva Perón: la mujer del látigo. Ed. La Reja. Buenos Aires.

Navarro, Marysa (1965). Los Nacionalistas. Ediciones Jorge Álvarez. Buenos Aires.

(1994). Evita. Planeta. Argentina. (http://www.lacampora.org/wp-content/uploads/ 2011/08/Navarro-Marysa-Evita.pdf; consultado 08 de septiembre de 2016).

(2000) El liderazgo carismático de Evita. La Aljaba. Segunda época. Vol. V. Dartmouth College, Estados Unidos. (http://www.biblioteca.unlpam.edu.ar/ pubpdf/aljaba/v05a02navarro.pdf; consultado el 09 de septiembre de 2016).

Organización Internacional del Trabajo. http://www.ilo.org/wcmsp5/groups/public/--dgreports/---cabinet/documents/genericdocument/wcms_371206.pdf.

(Consultado el 4 de abril de 2017).

Perón, Eva. (1951). La razón de mi vida. Ediciones Peuser. Buenos Aires. (La Baldrich - Espacio de Pensamiento Nacional. www.labaldrich.com.ar)

Presidencia de la Nación. Secretaría de Cultura. Instituto Nacional Juan Domingo Perón de Estudios e Investigaciones Históricas, Sociales y Políticas. (2006). Del poder al exilio: cómo y quienes me derrocaron. Instituto Nacional Juan Domingo Perón. Buenos Aires. (www.soloperonista.com/revistas/7_del_ poder_al_exilio.pdf; consultado el 07 de septiembre de 2016).

Sebreli, Juan José (2008). Comediantes y mártires: ensayo contra los mitos. Random House Mondadori S. A. Barcelona.

Ventura, Any (1997). Las mujeres que mandan: el poder de las mujeres en la Argentina menemista. Planeta. Argentina. 